\title{
Hindu Halk Dindarlığının Merkezindeki Yapılar: Yol Kenarı Tapinaklar1
}

\author{
Structures at the Center of the Hindu Community Piety: Wayside Shrines
}

\author{
Nermin ÖZTÜRKa \\ a Doç. Dr., Necmettin Erbakan Üniversitesi, Ahmet Keleşoğlu İlahiyat Fakültesi \\ e-Posta: nozturk@erbakan.edu.tr, http://orcid.org/0000-0003-2757-5798/
}

\begin{tabular}{cc}
\multicolumn{2}{c}{ Makale Bilgileri } \\
\hline Geliş Tarihi: & 01.03 .2019 \\
Kabul Tarihi: & 05.04 .2019 \\
Yayın Tarihi: & 26.06 .2019
\end{tabular}

\begin{abstract}
Özet
Hindistan'tn hem kentsel hem de kirsal alanlarında siklıkla karşılaşılan yol kenarı tapınakları Hinduların pek çoğu için ibadetin ayrılmaz parçasıdırlar. Bunlar, Tanrının her yerde hazır ve nazır olduğu şeklindeki Hint felsefesinden doğmuşlardır. Bu tapınakların bazıları herkesçe bilinen büyük tanrılara ait olsa da pek çoğu yerel tanrlara ve kutsanmiş şahsiyetlere aittir. Büyük tanrilar arasında hem resim ve heykel tarzındaki hem de diğer formlar ile Şiva başı çeker. Şiva'nın iki oğlundan biri olan fil başlı Tanrı Ganeş ile Maymun Tann Hanuman'a da bu tür tapınaklarda sıklıkla rastlanır. Yol kenarı tapınaklarının çoğunun sahibi olan yerel tanrılar ise bölgeden bölgeye değişebilir. Bunların yanı sıra Halk kahramanları, mitolojik şahsiyetler veya eşinin cenazesi töreninde onunla birlikte diri diri yakılan kadınlar adına yapılmıs yol kenarı tapınakları da vardır. Bu tapınaklar yapı formu olarak da oldukça çeşitlidirler. Pek çoklar, içine tek kişinin dahi giremeyeceği kadar küçük bir kulübeden ibaret, genellikle bir ağacın altına yapılmış, derme çatma ve basit yapılardır. Bunların içine "murti" denilen tanrı tasvirleri yerleştirilmiştir. Tapınak ibadetinin esasını oluşturan "darsan" yani Tanrıyı "görme" eylemi bu murtiler vasıtasıyla sağlanmaktadır. İçindeki murtisi ile küçük bir oda şeklindeki yol kenarı tapinakları aslında büyük tapinaklardaki "garbhagriha" yani rahim odası veya rahim boşluğu denilen özel kısmin muadilidir. Dolayısıyla yol kenarı tapınaklarının oldukça gösterişli ve teferruatlı olan büyük tapınakların en basit formu olduğu söylenebilir. Bazen ağacın kendisi tapınak haline getirilmiştir. Bu tür ağaçlar içerisinde Hint inciri olarak bilinen ve aynı zamanda Hindistan'ın ulusal ağacı da olan banyan ağacı özellikle dikkat çeker. Çok zengin çeşitlilikteki yol kenar tapınakları arasında seyyar olanlarına rastlamak dahi mümkündür. Bazen yol kenarı tanrıları tamamen açıtta da olabilirler. Buralardaki ibadet basit eylemlerden oluşur. Dua etmek, tütsü, ışık, yiyecek ve çiçek sunuları en çok yapılan eylemlerdir. Kutsal sayılan ağaçların gövdelerine ip dolamak da önemli bir ritüeldir. Bu uygulamaların çoğu dişardan, yüzeysel olarak bakıldığında batıl inanç olarak değerlendirilebilecek türdendir. İnsanlar buralara hem günlük ibadetler hem de sağlık, korunma, bağışlanma, kurtuluş gibi değişik amaçlarla giderler. Büyük tapınaklarda uyulması gereken katı dini kurallar buralarda uygulanmadiğı için yol kenarı tapınakları her kasttan ve sinıftan insana açıktırlar. Buralarda hizmet edenler sıklıkla kadınlar ve brahmin olmayanlardır, hatta aşağı kastların üyeleridir. Bazılarında kendini oraya adamış özel bir görevli bulunur. Kolay ulaşılabilirlikleri ve herkese açık olmaları onları halk dindarlığının merkezi haline getirmiştir.
\end{abstract}

Anahtar sözcükler: Hinduizm, İbadet, Yol Kenarı Tapınağı, Tapınak

\section{Giriş}

Bütün dinlerde kutsalla veya Tanrı ile temasa geçmeyi sağladığına inanılan kutsal mekânlar vardır. Oldukça çeşitli olan bu tür mekânlar içerisinde tapınaklar başı çeker. Tapınaklar ise kendi içlerinde en ince ayrıntıların bile düşünüldüğü ihtişamlı binalardan en 
basit muadillerine kadar çeşitlilik arz ederler. Bizim burada ele alacağımız konu da işte bu en basitlere örnek teşkil eden Hinduizm'deki yol kenarı tapınakları olacaktır. Konuyu ele alış nedenimiz ise bu tür kutsal mekânlara Hindistan'ın hangi kentinde olursa olsun neredeyse her sokakta rastlanması, günlük dini yaşamın çok önemli bir parçası olmaları, halk arasındaki popülaritelerinin büyük tapınaklara nazaran daha etkin olması, bunların çeşitlilikleri ve buralardaki gözle görülebilen veya müşahede edilebilen yoğun, aktif dini yaşam ve pratiklerdir.

Asıl konumuza geçmeden önce Hinduizm'de tapınağın tarihçesi ve anlamı hakkında kısaca bilgi vermek sanırız faydalı olacaktır. Dünyanın yaşayan en eski dini kabul edilen Hinduizm'de ilk tapınağın ne zaman ve nasıl ortaya çıktığı net olarak kimse tarafından bilinmese de ilk tapınakların kereste ve çamur gibi çabuk çürüyen malzemelerden yapıldığı, bunları doğal mağara ve oyma kaya tapınakların izlediği, sonrasında taş veya tuğla ile yapılanlara geçildiği bilinmektedir. Süslenmiş taş yapılar ve Tanrı tasvirleri ise daha sonraki periyoda aittir. ${ }^{1} \mathrm{Bu}$ dönem Upanişadlar sonrasına rastlar. Yoğun olarak mabetlerin ortaya çıkması ise VII. yüzyıl ve sonrasıdır. ${ }^{2}$

Tapınağı ifade etmek için kullanılan çok sayıdaki ismin arasında en bilinenleri ve sıklıkla kullanılanları mandir (bekleme yeri), prasada (lütuf yeri), devalayadır (Tanrı evi). Bu üçünün arasında en çok tercih edilen ise mandirdir. Mandirin bir Tanrının dünyevi evi olduğuna ve burada kendisine ibadet edenleri beklediğine inanılır. Bu inancın izleri Hindu kutsal metinlerinden destanlar ve Puranalar'a kadar gider. Şastralar gibi daha geç dönemlere ait kutsal metinlerde ise bir mandirin inşası hakkında yazılmış özel bölümler bulunur. Bu metinlerde mandir insanlık ve tanrılık dünyalarının karşılaştığ 1 yer olarak tanımlanır. Hindular Tanrının yeryüzüne tenzil ettiğine ve mandire yerleştirilen kutsal imaj vasıtasıyla şekil aldığına inanırlar. ${ }^{3}$ Çünkü Hinduizm'e göre Tanrı hem formlu hem formsuzdur, hem sonlu hem sonsuzdur, hem tektir hem çoktur. Tüm evrene ve ötesine yayllan, bilinen ve bilinmeyen tüm varlığı tanımlayan formsuz ruh parabrahman olarak bilinir. Çoğu insan için onun kavranması imkânsızdır. Soyut parabrahmanın insanlar tarafından anlașılmasını ve onunla iletişim kurulabilmesini mümkün hale getirmek için, felsefi olarak, onun üç kozmik fonksiyonu (yaratıc1lı, koruyuculuk ve y1kıc1lık) kişileştirilmiş ve bireysel formlara dönüştürülmüşlerdir. Bunlar Brahma, Vişnu, Şiva adlarıyla ve üçü birlikte trimurti olarak bilinirler, insanüstü karakterler olarak tanımlanır ve gelişmiş insan davranışları için rehberlik ederler. ${ }^{4}$ Başta bunlar olmak üzere Hinduizm'deki tüm tanrılar ve tanrıçalar aslında parabrahmanın formlarıdırlar. Tapınaklarda yapılan ibadetlerde 5 bireyin zihninin yaptığı şeye yoğunlaşabilmesi amacıyla bu formların murti olarak adlandırılan tasvirleri bulunur. Her bir murti farklı bir isimle Tanrının farklı bir yönünü temsil eder. Büyük tapınaklarda o tapınağın esas tanrısının murtisi garbhagriha denilen en içteki hücreye yerleştirilir. ${ }^{6}$ Garbhagriha kelime anlamı itibarıyla "rahim boşluğu/odası" demektir. ${ }^{7}$ Tapınağın en önemli kısmı olan bu hücre 8 Süleyman Mabedindeki "kutsalların kutsalı" odasına benzetilebilir. Burası küçük, karanlık, penceresiz, kare şeklinde ve girişi doğu yönünde olan bir yapıdır, ${ }^{9}$ üzerinde Güney Hindistan'da vimana, Kuzey Hindistan'da shikhara denilen piramit şeklinde bir kule bulunur. ${ }^{10} \mathrm{Bu}$ kule Hinduizm'deki kutsal Meru dağını temsil eder.11 Çoğu tapınaklarda garbhagrihaya yalnızca din görevlilerinin girmesine izin vardır, diğerleri murtiyi ancak

\footnotetext{
${ }^{1}$ Swami Harshananda, All About Hindu Temples, Chennai: Sri Ramakrishna Math, 2001, 2.

2 Ahmet Güç, Dinlerde Mabed ve İbadet, Bursa: Esra Fakülte Kitabevi, 1999, 60-61.

${ }^{3}$ Madhu Bazaz Wangu, Hinduism, New York: Chelsea House, 2006, 92.

${ }^{4}$ Stephen P. Huyler, "Hinduism: The One and the Many", Pratapaditya Pal, Stephen P. Huyler, John E. Cort, Christian Luczanits, Debashish Banerji, Puja and Piety: Hindu, Jain, and Buddhist Art from the Indian Subcontinent, Edit. Pratapaditya Pal, Oakland: Univ of California Press, 2016, 55.

5 Burada kastedilen şey pucadır ve zaten Hinduizm'de ibadet denilince genellikle puca anlaş1lır. (Robert E. Van Voorst, RELG: World, Wadsworth: Cengage Learning, 2014, 81.)

6 Roshen Dalal, Hinduism: An Alphabetical Guide, New Delhi: Penguin Books, 2014, 411; Satguru Sivaya Subramuniyaswami, Dancing with Siva: Hinduism's Contemporary Catechism, Hawaii: Himalayan Academy Publications, 2003, 235.

${ }_{7}$ Stella Kramrisch, The Hindu Temple, Calcutta: University of Calcutta, 1946, C. 1, 162; Adam Hardy, Indian Temple Architecture, Form and Transformation : the Karnăta Drävida Tradition, 7th to 13th Centuries, New Delhi: IGNCA, 1995, 16.

8 Kramrisch, The Hindu Temple, 163.

9 Roshen Dalal, The Religions of India: A Concise Guide to Nine Major Faith, New Delhi: Penguin Books, 2006, 364; Hardy, Indian Temple Architecture, 16.

10 Kindersley Dorling, Roshen Dalal, India, London: Dorling Kindersley, 2008, 24.

${ }^{11}$ Alain Danielou, The Hindu Temple: Divinization of Eroticism, Rochester, Vt: Inner Traditions, 2001, 54.
} 
dışarıdan görebilirler. ${ }^{12}$ Onu görebilmek için en ideal zaman gün içerisindeki belli vakitlerdir. Bu anlarda Tanrı tasviri taze çiçeklerle en güzel şekilde süslenir ve görünmesi için örtüler kaldırılır. ${ }^{13}$ Daha önceleri kirli sayılan kastlar ve özellikle dokunulmazlar (harijanlar ${ }^{14}$ ) bir tapınağın dıştaki kısmına bile alınmazdı, avluda durmak zorundaydılar. ${ }^{15}$ Hatta bunların içinden bazıları öyle kirli görülürlerdi ki büyük tapınakların bahçelerine dahi girmelerine izin verilmezdi. ${ }^{16} \mathrm{Bu}$ durum Hindistan'ın bağımsızlığını kazanması ve ardından anayasasının ilanı (1950) ile resmen ortadan kaldırılmıştır. Hiçbir sınıf ve kast ayrımı gözetilmeksizin bütün insanların her tür tapınağa girmesine izin verilmiştir. ${ }^{17}$ Tapınakların kullanımıyla ilgili bu özgürleşme süreci konumuz açısından önemlidir. Fakat anayasaya rağmen, geçmişte konulan ve gücünü dinden alan bu kuralların toplumsal bazda ne derece uygulandığ sorgulanabilir.

Hindular için tapınağa gitmekteki esas amaç Tanrıyı görebilmektir ve burası Tanrının insana görünür olduğu yerdir. 18 İnançlarına göre kutsal imajları görmek ve onlara dokunmak suretiyle, insan geçici olarak boyut değiştirilebilir ve kutsalı deneyimlemek mümkün olabilir. ${ }^{19} \mathrm{Bu}$ yüzden bir Hindu tapınağa giderken ibadet etmeye gittiğini söylemez, bunu yerine darsana gittiğini söyler, yani "Tanrıyı görmeye". Darsanın anlamı "görme"dir, bazen "kutsalın kutlu bakıșı" diye çevrildiği de olur. Bu sözcük bireye ibadetin sadece bir dua ve sunu konusu olmadığını ama kalbin adanmışlık durumu olduğunu hatırlatması açısından önemlidir. ${ }^{20}$

Hindu anlayışına göre Tanrı tasvirde mevcuttur, tasvirin görsel kavranışı onun dini manasiyla yüklüdür. Tasviri seyretmek veya ona bakmak bir ibadet eylemidir ve gözler sayesinde kişi Tanrının kutsamasını kazanır. Dolayısıyla Hindu tapımının merkezi davranışı Tanrının huzurunda durmak, Tanrı tasvirini kendi gözleriyle görmek, aynı zamanda Tanrı tarafından da görülmektir. ${ }^{21}$ Tanrının insana görünür olma veya Tanrı ile insan arasındaki ilişkinin sağlandığ bu süreç kompleks bir sembolizm içeren bir dizi inanç ve fikirden oluşur. Tapınakta yapılan dinamik ritüeller bu fikirlerin gerçekleşmesine izin verirler. Bunlar sayesinde insanın illüzyon ${ }^{22}$ dünyasından hakikate ve gerçek bilgiye erişebileceğine inanılır. İllüzyondan kurtulmak demek zaten Hindu dininin amacı olan kurtuluşa yani mokşaya ulaşmak demektir. Mekân bazında tapınaklar bu değişimin gerçekleștiği yerlerdendir. Bu yüzden tapınak mimarisi insan ve Tanrı arasındaki ilişkiyi sağlamak üzere dizayn edilmiştir. ${ }^{23}$ Bir tapınağın nasıl olup da insan ve Tanrının karşılaştıkları yer olduğunu anlamak için onun sembolik anlamlarını kavramak gerekir. Kutsal tasvirler veya murtiler Tanrının yaratma, yıkım, güç, zenginlik, koruma gibi farklı yönlerini temsil ederler. Ritüellerde, dualarda ve puca sırasında kullanılan, insan eliyle yapılmış bu nesnelerde oldukça zengin bir sembolizm vardır, ${ }^{24}$ fakat Hindular murtileri sadece bir sembol olarak görmez, ibadet sırasında Tanrının onlarda hazır ve nazır olduğuna inanırlar. ${ }^{25}$

Kutsalın direkt deneyimi için biricik yol tapınağa gitmek değildir. ${ }^{26}$ İbadet evlerde, yol kenarı tapınaklarında ve hac yerlerinde de yapılır. Bu hac yerleri mesela kutsal nehirler gibi doğal alanlar olabildiği gibi insanlar tarafindan inşa edilmiş özel alanlar da olabilir. ${ }^{27}$ Aslına bakılırsa ev, resmi tapınaklardan daha önemli bir tapım yeridir. Bu iş için duvarda bir niş veya odanın bir köşesi, hatta bazen özellikle büyük evlerde görüldüğü gibi, bir odanın tamamı ayrılmıştır. Buraya murtiler veya Tanrının çerçevelenmiş resimleri konur. Tapınakta yapılan

\footnotetext{
12 Dalal, Hinduism, 411.

${ }^{13}$ Diana L. Eck, Darsan: Seeing the Divine Image in India, Delhi: Motilal Banarsidass Publishe, 2007, 3.

${ }^{14}$ Harijan "tanrının çocukları" anlamındadır. Tüm dünyanın insan hakları savunucusu olarak kabul ettiği Hindistan bağımsızlığının kurucu lideri Mahatma Gandi, toplumun büyük bir kesiminin hor görüp aşağıladığı dokunulmazlara (parya) bu ismi vererek onları onurlandırmıştır.

${ }_{15}$ Govind Sadashiv Ghurye, Caste and Race in India, London: Kegan Paul, Trench, Trubner 1932, 14.

16 Ghurye, Caste and Race, 9

17 Alfred Prabhakar Barnabas, Social Change In A North Indian Village, New Delhi: Indian Institute of Public Administration, 1969, 86.

18 George Michell, The Hindu Temple: An Introduction to Its Meaning and Form, Chicago and London: University of Chicago Press, 1988, 61.

${ }^{19}$ Wangu, Hinduism, 92

20 Eck, Darsan, 3.

${ }^{21}$ Eck, Darsan, 3.

${ }^{22}$ Hinduizm'de buna 'maya' inanc1 denir.

${ }^{23}$ Michell, The Hindu Temple, 61

${ }^{24}$ Wangu, Hinduism, 92.

${ }^{25}$ Huyler, "Hinduism", 55.

${ }^{26}$ Huyler, "Hinduism", 55.

${ }^{27}$ Gavin D. Flood, An Introduction to Hinduism, New York: Cambridge University Press, 1996, 198.
} 
ritüelin yani pucanın daha sadesi hane reisi tarafindan uygulanır. ${ }^{28}$

Bir Hindu'nun dini yaşamında kurumsal tapınaklar ve ev tapınaklarının dişında yol kenarı tapınaklarının hayati bir önemi vardır. Araştırmalar sayıca bunların kurumsal dini yapılardan daha fazla olduğunu göstermektedir.

\section{Yol Kenarı Tapınaklarının Kavramsal Çerçevesi}

Yol kenarı tapınakları ismi onlara bulundukları yer itibarıyla verilmiştir. Sokak tapınakları veya sıklıkla kaldırımlarda bulundukları için "kaldırım tapınakları" da denmektedir. Bunun yanı sıra büyüklüklerine göre de isimlendirildikleri olur; mini tapınak, minyatür tapınak veya küçük tapınak gibi. Bu tip tapınakların en önemli özellikleri arasında konumları, görünürlükleri ve ulaşılabilirlikleri sayılabilir. Bunlar bir kamu yoluna bitişiktirler, herkesin görebileceği bir yerdedirler ve yoldan geçen herkes tarafından rahatlıkla ulaşılabilecek pozisyondadırlar. ${ }^{29}$ Onları büyük tapınaklardan ayıran özellikler ise şöyle sıralanabilir: Büyük tapınaklara göre çok daha küçük ve gösterişsizdirler. Kutsal ve profan alan arasındaki sınır büyük tapınaklardaki kadar açık tanımlanmamıştır. Tanrı ile ibadet eden arasinda aracilık eden bir din görevlisi normalde bulunmaz. ${ }^{30}$

Yol kenarı tapınakları yapısal olarak büyük bir çeşitlilik gösterirler. Genellikle kurumsal tapınaklara nispetle çok daha az ayrıntılı, basit, gösterişsiz ve küçük bir oda görünümündedirler. ${ }^{31} \mathrm{Bu}$ küçük oda veya mekân Tanrının meskeni olmak üzere inşa edilmiştir ve içinde bir murti bulunur. Fakat burada küçüklük sübjektif bir kriterdir, zira onların büyüklükleri değişebilir. İlk etapta insanların onların içine girmesi maksadı ile inşa edilmediklerinden son derece küçüktürler, fakat dinamik yapılar olmalarından ötürü zamanla büyüyebilirler ve genişleyebilirler, ${ }^{32}$ hatta orta büyüklükte bir tapınağa bile dönüşebilirler. ${ }^{33}$ Boyutları büyüdükçe mimari detayları da artar. İçine kimsenin giremeyeceği kadar küçük ve çok derme çatma olanların yanı sıra birkaç kişinin sığabileceği ölçekte olanlarına da sıklıkla rastlanır. Kimilerinde ön cephe açıktır ve tamamıla korunmasızdır, kimilerinde ise geçici olarak kapatılır. ${ }^{34} \mathrm{Bu}$ daha çok içindeki tanrı imajını korumak maksadıyla puca dişındaki zamanları kapsar. ${ }^{35}$

Yol kenarı tapınaklarının kaldırımlara yapılması ve yayaların hakkına tecavüz edilmesi sik rastlanan bir durumdur. Hatta bazen bir yolun ortasına bile yapilabilirler. Aralarında özel bir yere, bir duvara ve ölü yakılan yere kurulanları vardır. Çoğu sabitlenmiş yapılar olmalarına karşın mobil olanları vardır. Bunlar yaya olarak taşınabildikleri gibi motorize araçlarla da taşınabilirler. Bazıları geçicidirler, bazıları festivallerin gelissiyle dönemsel olarak ortaya çıkarlar. ${ }^{36}$ Bazen de bu tür tapınakların hiç kapalı alanı bulunmaz, tamamen açık havadadırlar ve Tanrı'yı temsilen sadece zincifre boyası veya zerdeçalla (kırmızı renk ile) işaretlenmiş basit bir taş kullanılmış olabilir. ${ }^{37}$ Banyan $^{38}$ gibi bazı ağaçlar kutsal kabul edilir ve bunlar da bir yol kenarı tapınağı olarak kullanılır. Hindistan'in hemen her yerinde ağaç tapınaklara sıklıkla rastlanır. Bazen bir ağacın altında yol kenarı tapınaklarının birkaç çeşidini görmek bile mümkündür. Yan yana dizilmiş tek bir ikon, bir niş ve piramit şeklindeki çatısıyla küçük bir hücre, sanki bir tapınağın evriminin değişik safhalarını sergiliyormuşçasına tüm tapınak tiplerini birleştiren bir yapıdır. ${ }^{39}$

İçindeki murtisi ile minik bir oda şeklindeki yol kenarı tapınakları aslında büyük tapınaklardaki garbhagrihanın muadilidir. Dolayısıyla yol kenarı tapınaklarının oldukça teferruatlı, gösterişli ve büyük tapınakların en basit formu olduğu rahatlıkla söylenebilir. ${ }^{40}$

\footnotetext{
28 Nila Pancholi, "Hinduism", Six World Faiths, Edit. W. Owen Cole, London, New York: Continuum, $2002,21$.

29 Borayin Larios, Raphaël Voix, "Introduction. Wayside Shrines in India: An Everyday Defiant Religiosity, South Asia", Multidisciplinary Academic Journal, 18 | 2018, 3-6. URL : http://journals.openedition.org/samaj/4546 ; DOI : 10.4000/samaj.4546. Erişim: 20.10.1018

${ }^{30}$ Stephen Jacobs, Hinduism Today: An Introduction, London and New York: Continuum, 2010, 46.

${ }^{31}$ Denise Cush, Catherine Robinson, Michael York, Encyclopedia of Hinduism, London \& New York: Routledge, 2008, 789.

${ }^{32}$ Larios ve Voix, "Wayside Shrines", 7.

${ }^{33}$ Yasumasa Sekine, "Sacralization of the Urban Footpath, with Special Reference to Pavement Shrines in Chennai City, South India.", Temenos 42(2), 2006, 80.

${ }^{34}$ Larios ve Voix, "Wayside Shrines", 7.

${ }^{35}$ Street shrine Susan Lewandowski, "The Hindu Temple in South India", Buildings and Society: Essays on the Social Development of the Built Environment, Edit. Anthony D. King, London: Routledge, 2003, 79.

${ }^{36}$ Larios ve Voix, "Wayside Shrines", 6.

37 Joyce Flueckiger, Everyday Hinduism West Sussex: Wiley-Blackwell, 2015, 109.

38 Bir tür incir ağacı, Hint inciri adıyla da bilinir.

39 Vinayak Bharne, "Anointed Cities: The Incremental Urbanism of Hindu India", The Emerging Asian City: Concomitant Urbanities and Urbanisms, Edit. Vinayak Bharne, New York: Routledge, 2013, 19.

40 Vinayak Bharne, Krupali Krusche, Rediscovering the Hindu Temple, The Sacred Architecture and Urbanism of India
} 
$\mathrm{Bu}$ form ibadetin özüne göre tasarlanmıştır ve bu özün darsan olduğunu yukarıda belirtmiştik. Bu yüzden yol kenarı tapınaklarının merkezinde kutsalı temsil eden bir obje vardır. Bu obje çok değişik şekillerde karşımıza çıkar. O bazen bir ikon şeklindedir, bazen yarı ikoniktir veya ikonik olmayabilir de, ilaveten üç boyutlu da olabilir iki boyutlu da. Söz gelimi orijinal bir tablo ya da fotokopi olarak basılmış ve çerçeveletilmiş bir resim olabilir. Bu obje ilahi aşkın gücü temsil eden bir sembol olabileceği gibi, halkın ermiş kabul ettiği bir şahsı hatırlatan herhangi bir eşya da olabilir veya doğrudan doğanın kendisinden olabilir, mesela ağaç gibi. Örnekleri çoğaltmak mümkündür. Bu konuda özetle söylemek gerekirse yol kenarı tapınaklarındaki kutsal imajları kutsalın tek bir türü ile sınırlı değildir. Bu imaj ne kadar basit olursa olsun "ilahi gücün" materyal enkarnasyonu olarak düşünüldüğünden Hindular açısından tapinılacak bir şeydir. ${ }^{41}$

Yol kenarı tapınaklarının ne zaman ve nasıl ortaya çıktığı bilinmemekle birlikte en basitinden en kompleksine kadar tüm Hindu tapınaklarının felsefi, mimari, dini ve kültürel varlıklarının antik Veda metinlerinden türediği kabul edilmektedir. ${ }^{42}$ Normalde büyük tapınakların inşası en başından itibaren bir dizi kural gerektiren resmi bir süreçtir. ${ }^{43}$ Fakat yol kenarı tapınaklarının resmi bir tarihleri yoktur, ya anonimdirler ya da bireysel bir kurucu ile bağlantılıdırlar. Kendileri hakkında yazılı bir tarihten mahrum oluşları onların en belirgin özelliklerinden birisidir. Onların tarihleri bir takım sözlü ve tartışmalı aktarımların toplanmasına ihtiyaç gösteren popüler tarihin içinde gizlidir. Çünkü onlar bazen spontane olarak, bazen bireysel deneyimlere cevap olarak gayri resmi şekilde veya bazen de bir Tanrının kendini açığa vurmak istediği bir vizyon gibi muhtelif şekillerde ortaya çıkarlar. Pek çok yol kenarı tapınağı kendini Tanrıya adamışların vizyonlarının sonucudur. ${ }^{44}$ Enteresan bir şekilde bir gece ansızın ortaya çıkabilirler. Mesela üzerine dini işaret yapılarak kaldırıma bırakılan bir tuğla tapınağın ilk habercisi olabilir. Sonra bunun yanında küçük bir bağıș kutusu belirir. Yeterli fon elde edilince burada kalıcı bir oda inşa edilir ve içine bir Tanrı tasviri yerleştirilir. Teoride kaldırıma bir şey inşa etmek için belediyelerden resmi izin alınması gerekirken bunlar kural tanımazlar, 45 ayrıca bir Hindu tapınağının resmi kurallarını da takip etmezler. Ana yönlere oryantasyonları planlanmamıştır. Resmi tapınakların doğu-batı yönündeki hizalanmalarına ters olacak şekilde yönleri her tarafa doğru olabilir ve kurumsal tapınakların hijyenik kurallarına buralarda uyulmaz. Bu tapınaklar gezip dolaşan hayvanlar dahil her şeye ve herkese açıktır. ${ }^{46}$ Kaldırımlara tapınak yapanlar genellikle bu tapınağı bir rüyadan sonra inşa ettiklerini söylerler. Rüyalarında bir Tanrı onlardan bunu yapmalarını istemiștir. ${ }^{47}$ Bazen tabiattaki doğal bir form bir tanrı imajına benzetilip kutsallaştırılabilir ve yol kenarı tapınağına dönüştürülebilir. Hindistan'ın metropol şehirlerinden olan Madras'daki bir tapınak buna örnek olarak verilebilir: Uzun yıllar önce bir adam burada şekli fil başlı tanrı Ganeş'e benzeyen bir ağaç keşfetmiş. Ağacın budaklı gövdesi Ganeş’in başına benziyormuş. Adam ona ibadet etmeye başlamış ve onu terk etmeyeceğine yemin etmiss, sonra orada din adamı olarak hizmete başlamış. Bu ağaç üniversitenin yakınında olduğu için özellikle öğrenciler tarafından sınav öncesi çokça ziyaret edilen bir tapınak haline gelmiştir. ${ }^{48}$ Zaten bir yol kenarı tapınak formu olarak en sık rastlanan doğal objeler arasında ağaçlar başı çeker. Gölgesi altında yağ sürülmüş bir taș veya bir tanrı tasviri bulunması, bayrak ya da flama gibi bir șeyle ișaretlenmesi ve bazen de gövdesinin tanrının kendisiymiș gibi giydirilmiș olması bir ağacın yol kenarı tapınağı olduğunun basit bir göstergesidir. Bir tapınak formu olarak özellikle bazı ağaç türleri dikkat çekerler. Mesela Hindistan'da ashvattha denilen Hint inciri ağacı trimurtiyi temsil eder; kökleri Brahma'dır, gövdesi Vişnu'dur, yaprakları Şiva'dır.

\footnotetext{
Newcastle: Cambridge Scholars Publishing 2012, 19.

${ }^{41}$ Larios ve Voix, "Wayside Shrines", 6.

42 Bharne ve Krusche, Rediscovering the Hindu Temple, 254.

${ }^{43}$ Hindular tapınak için bir yer seçtiklerinde, o yerin ruhlarını inşaat başlamadan önce ritüel olarak kovarlar. Sonra toprak sürülür ve birkaç tohum ekilir. Bu tohumlardan çıkan bitkilerin kalitesi gözlemlenerek toprağın, dolayısılla tapınak yapılacak yerin kalitesi hakkında karar verilir. Uygun görüldüğü takdirde toprak bir ayna olana kadar düzeltilir. Hazırlanan yere göğü temsilen bir daire, dairenin etrafına da yeri temsilen bir kare çizilir. Bu dairenin merkezinde gök ile tapınağı bağlayan kutsal bir direk oluştuğuna inanılır. Bu direğin dibine içinde tohumlar ve mücevherler olan ve tapınağın özünü temsil eden bir sandık gömülür. Tapınağın en önemli kısmını oluşturan garbhagriha yani en kutsal oda veya "kutsalların kutsalı" bunun üstüne inşa edilir. (Wangu, Hinduism, 95, 96.)

44 Larios ve Voix, "Wayside Shrines", 9-10.

45 Lewandowski, "The Hindu temple in south India", 79

46 Bharne, "Anointed Cities", 47.

47 Sekine, "Sacralization of the Urban Footpath", 80.

48 Satguru Sivaya Subramuniyaswami, Loving Ganesha: Hinduism's Endearing Elephant-Faced God, USA and India: Himalayan Academy, 2000, 265.
} 
Bazıları Krişna'nın bu ağacın altında öldüğüne inanır ve Skanda Purana'ya göre bu ağacı kesmek günahtır. Bu tür kutsal ağaçlar öldüğünde bile yerleri kutsal olarak kalır. Çünkü geçmişte buralarda gerçekleştirilen sayısız ritüelin enerjilerinin her daim sürdüğüne inanilir. 49

Bazen bu tapınaklar belli maksatlarla belli yerlere yapılır. Mesela kazaların çok olduğu yerlere koruyucu olması amacıyla bir Tanrı imajı yerleştirilir. Bunlardan biri tanrıça Kumkum Kaliamma'dır, özellikle tehlikeli bir yola yerleştirilmiştir. Yine köyün veya kasabanın su kaynağını koruması için tapınılan tanrılar vardır. Bunlar için yapılan yol kenarı tapınakları su tanklarının veya havuzlarının yanına inşa edilmiştir. ${ }^{50}$ Bir başka örnek orman yolunu korumak üzere yapılan tapınaklardır. ${ }^{51}$ Örnekler çoğaltılabilir.

Aslında yol kenarı tapınaklarının tanrıları sayılamayacak kadar çok ve özgündür. Onlar, başta yerel tanrılar olmak üzere, herkesin çok aşina olduğu tanrılar ${ }^{52}$ ve kutsallaştırılmış atalar da olabilir. ${ }^{53}$ Büyük tanrılardan Şiva yol kenarı tapınaklarında daha çok ikonik olmayan tarzda siyah bir taş (linga) ile temsil edilir. Erilin simgesi linga, dişilin simgesi olan yoni ile birliktedir. İkisi beraber eril ve dişilin yaratıcı ve üretici gücünü temsil ederler. Linga, ona tapinanlar tarafindan SSiva'nın kendisiyle bir tutulur. Maymun tanrı Hanuman'a evde ve resmi tapinaklarda Rama ve ailesiyle birlikte tapinılırken yol kenarı tapınaklarında o, parlak turuncu renge boyanmış kaba bir tasvir olarak ve tek başına bulunur. 54

Araştırmaların sonuçları bu tür tapınaklarda en çok tercih edilen Tanrının Ganeş olduğunu göstermiştir. ${ }^{55}$ Fakat bu yapıların pek çoğu tanrılara değil tanrıçalara adanmıştır. Tüm Hindistan'da ama bilhassa Güney Hindistan'da popüler olan ve Nakamal adıyla bilinen yılan tanrıça tapımına yol kenarı tapınaklarında sıklıkla rastlanır. Yılan/naga tapımı ağaçlarla, özellikle de nim ağacı ile ilişkilidir. Bir ağacın dibine kobra şeklinde stilize edilen yılan taşları bu tapımın işaretleridir. ${ }^{56}$ Gramadevatalar da aynı şekilde yol kenarlarında en sık rastlanan ve neredeyse tamamı dişil olan köy tanrılarıdırlar. ${ }^{57}$ Bilindiği üzere Hindistan nüfusunun büyük çoğunluğu köylerde yaşar ve bu yüzden köy kültürü esastır. Bu bağlamda en önemli ve güçlü ilahi varlıklar gramadevatalardır. Bir gramadevata köy ile özdeşleşmiş ve köylülerin kendisine karşı özel bir ilgi ve sevgi duyduğu tanrıdır. Standart bir köyde bunlardan birkaç tane bulunur ve hepsinin görevleri ve isimleri farklıdır. Sayıları Hindistan'daki köylerin sayısından fazladır ve genellikle antropomorfik yapıda değillerdir. Daha çok yontulmamıs taşlarla ve ağaçlarla veya içinde antropomorfik bir tanrı bulunmayan minik tapınaklarla temsil edilirler. ${ }^{58}$ Bazı yerlerde daimi bir tapınakları dahi olmaz. Festival zamanlarında, mesela bambu gibi maddelerden, geçici olarak bir tapınak yapılır ve Tanrıyı temsil eden nesne bunun içine yerleştirilir. Dahası çok az gelişmiş, oldukça ilkel şartların yaşandığ1 köylerde bu temsili nesne bile sürekli olarak bulunmaz. Festival zamanlarında, mesela bir çömlekçi tarafından tanrıçanın çamurdan bir figürü yapılır ve festival sonrasında köyün dişına atılır. ${ }^{59}$ Köylüler onlara Hindu panteonunun büyük tanrılarından daha çok tapınır. Çünkü gramadevatalar köylülerin salgın hastalıklar, ani ölümler, doğal afetler gibi yerel sorunları ve varoluşsal kaygılarıyla daha çok ilgilidirler. 60

Köy tanrılarından olan ve genellikle bir ağacın altında dizilmiş yedi kutsal taş ile simgelenen sabtamatrika/yedi analar veya sabtakannimar/yedi kızlar en çok ziyaretçi alan yerlerdendir. ${ }^{61}$ Bunların koruyucu tanrılar olduklarına inanılır fakat isimleri bölgeden bölgeye değişebilir. Racastan'da bazı yol kenarı tapınakları ise yerel satilere adanmıştır. Satiler

\footnotetext{
${ }^{49}$ Bharne ve Krusche, Rediscovering the Hindu Temple, 21-22.

50 Cush vd., Encyclopedia of Hinduism, 790.

${ }^{51}$ Flueckiger, Everyday Hinduism, 109.

52 Sekine, "Sacralization of the Urban Footpath", 80.

53 Flood, An Introduction to Hinduism, 1.

54 Flueckiger, Everyday Hinduism, 24-25.

55 Sekine, "Sacralization of the Urban Footpath", 83; Mary E. Hancock, The Politics of Heritage from Madras to Chennai, Bloomington, IN: Indiana University Press, 2008, 87.

56 Cush vd., Encyclopedia of Hinduism, 789.

57 Bharne ve Krusche, Rediscovering the Hindu Temple, 22; Flueckiger, Everyday Hinduism, 109.

58 David Kinsley, Hindu Goddesses: Visions of the Divine Feminine in the Hindu Religious Tradition, Berkeley, Los Angeles and London: University of California Press, 1986, 197.

59 Henry Whitehead, The Village Gods of South India, Calcutta: Association Press, 1921, 36.

60 David Kinsley, Hindu Goddesses: Visions of the Divine Feminine in the Hindu Religious Tradition, Berkeley, Los Angeles and London: University of California Press, 1986, 197.

${ }^{61}$ Bharne ve Krusche, Rediscovering the Hindu Temple, 22; Cush vd., Encyclopedia of Hinduism, 790.
} 
bilindiği üzere kocasının cenaze ateşinde yanarak hayatlarına son veren eşlerdir. ${ }^{62}$

\section{Yol Kenarı Tapınaklarının İşlevsellikleri ve Uygulamalar}

Yol kenarı tapınakları kasaba ve şehirlerin yanı sıra özellikle kırsal kesimde yaygın bir kullanıma sahiptirler ve ibadetin ayrılmaz bir parçasıdırlar. Tanrı ile iletişim kurmanın en mütevazı yollarından birini sağlarlar. Çoğu insan için bireysel özgürlüklerin olduğu yerlerdir.

Yol kenarı tapınakları herhangi bir dini gruba ait değillerdir, her kasttan ve mezhepten olan insanlara açıktırlar. Bu yüzden birçok geleneğe ait semboller ve imajlar içerirler. Buralarda ibadet bireysel ve basittir, tanrılar açıktadır. ${ }^{63}$ Dolayısıyla insanlar doğrudan Tanriya ulaşabilirler, fiziksel olarak dokunabilirler ve dualarını sunabilirler. Oysa resmi tapınaklarda bu hususta bir sınırlama vardır, sıradan vatandaşların Tanrı ile doğrudan irtibata geçmesi mümkün değildir ve bir din görevlisine ihtiyaç vardır. ${ }^{64}$ Normalde yol kenarı tapınaklarının en popüler olanlarında bile festival zamanları dişında bir pujari bulunmaz. Buraların görevlileri sıklıkla kadınlar ve brahmin olmayanlardır, 65 hatta aşağı kastların üyeleridir. ${ }^{66}$ Bazılarında kendini oraya adamış özel bir görevli bulunur. ${ }^{67}$ Tapınak hizmetlerini aile yadigârı olarak sürdürenler vardır. Tapınağa günlük ibadet için gelenler bağış kutusuna (hundi) para koyarlar, yıllık festivaller sırasında çevreden bağışlar toplanır. ${ }^{68}$ Bazı tapınaklarda sabah ve akşam pucalarını yaptırmak üzere bir din görevlisi kiralandığı da olur. 69

Yol kenarı tapınakları neredeyse sonsuz çeşitlilikte kendilerini göstermelerine rağmen işlevsellik bakımından aralarındaki benzerlikler oldukça fazladır. Onlar, günlük ibadetler, festival zamanlarındaki törenler veya özel amaçlar gibi nedenlerle aktif dini yaşamın vazgeçilmez parçasıdırlar. Kentsel yaşamda neredeyse her sokakta bunlardan biriyle karşılaşılması ve darsan için belli kuralların olmayışı gündelik yaşamın yoğun koşturmacası içindeki insanlara özellikle gündelik ibadetler için bir kolaylık sağlar. Bunun için insanlar evlerine veya işyerlerine yakın ya da mesela otobüs durağı gibi bekleme yerlerindeki tapınakları tercih ederler. Vasıta beklerken geçen süre ibadet ederek değerlendirilir. ${ }^{70}$

İnsanlar bir yol kenarı tapınağının önünden geçerlerken avuçlar karşılıklı olarak birbirine bakacak ve parmak uçları yukarı gelecek şekilde ellerini göğüs hizasında birleştirip başlarını hafifçe öne eğerek, içlerinden okudukları bir dua ile saygılarını sunarlar (pranam). Yahut da sağ elleriyle önce kutsal imajına sonra kendi alınlarına art arda dokunurlar ve bu basit tapınma eylemini tamamlamak için bazen secde ederler. ${ }^{71} \mathrm{Bu}$ selamlama eylemi pucanın en basit formu olarak bilinir. Hinduizm'de bütün ritüeller bir tanrıya puca yapma üzerine kuruludur ve en basitinden en kompleksine kadar bütün pucalarda amaç ibadet eden ile edilen arasındaki yoğun duygu ortaklığını yakalamaktır. Bunun, puca sırasında âbid ile mâbud arasındaki fiziksel, zihinsel ve ruhsal bağlantı ile sağlandığına inanılır. Bireyin amacına ve Tanrı imajına göre puca basitten teferruatlıya değişebilir. ${ }^{72}$

Şayet insanların zihinlerinde özel istekleri varsa puca daha dikkatli ve ayrıntılı olur. ${ }^{73}$ Mesela bir nakamal yani yılan tanrıça için en uygun yiyecek sunulari ${ }^{74}$ süt ve yumurtadır. Yılan tapınaklarının en sik görüldüğü yerler gövdesinin dibine naga taşlarının yerleştirildiği ağaçlardır. Yılanlar çok güçlü varlıklar olarak düşünülür ve her yıl yılan 1sırmasıyla ölen pek çok insan yüzünden onlardan korkulur. Fakat aynı zamanda bu durumun tam tersine onlar, doğurganlığın gücü olarak da tanımlanır. İşte ağaçların köklerinde yaşadığına inanılan bu hayvanlara hem kısırlık konusunda kendilerine yardım etmeleri hem de bir kötülüğe sebep olmasınlar diye potansiyel güçlerini döndürmek için ağaçların dibine süt dökülür ve yumurta birakilır. ${ }^{75}$

Sadece yılan tanrıçalar değil ama bazı yol kenarı tapınakları çocuk verme güçleriyle

\footnotetext{
${ }^{62}$ Cush vd., Encyclopedia of Hinduism, 789.

${ }_{63}$ Cush vd., Encyclopedia of Hinduism, 790.

64 Vineeta Sinha, Religion and Commodification: Merchandizing Diasporic Hinduism, London: Routledge, $2010,72$.

65 Albertina Nugteren, Belief, Bounty, and Beauty: Rituals around Sacred Trees in India, Leiden: Brill, $2005,346$.

66 Flueckiger, Everyday Hinduism, 109.

${ }^{67}$ Subramuniyaswami, Loving Ganesha, 265; Larios ve Voix, "Wayside Shrines", 9.

68 Sekine, "Sacralization of the Urban Footpath", 87.

${ }^{69}$ Sekine, "Sacralization of the Urban Footpath", 86.

${ }_{70}^{70}$ Larios ve Voix, "Wayside Shrines", 7-8.

${ }^{71}$ Nugteren, Belief, Bounty, and Beauty, 346.

${ }^{72}$ John A. Grimes, Ganapati: Song of the Self, Albany, NY: SUNY Press, 1995, 166.

73 Nugteren, Belief, Bounty, and Beauty, 346.

${ }^{74}$ Bir tanrı imajına yiyecek-içecek sunmak normal bir pucanın gereklerindendir. Bunların yanı sıra 1şık, çiçek, para, tütsü gibi değişik türde sunular da kullanılır.

75 Cush vd., Encyclopedia of Hinduism, 789.
} 
ünlüdürler. Bu tapınaklar, ister ağaç şeklinde isterse küçük bir kulübe şeklinde olsun, görüntüleri ile kendilerini derhal belli ederler. Kadınlar bunlara kırmızı ve sarı ipler bağlarlar ve siklıkla tahta beşikler de asarlar. ${ }^{76}$

Bir ağacın yol kenarı tapınağı olup olmadı̆̆ı diğer ağaçlarla görsel olarak kıyaslandığında rahatlıkla anlaşılır. Dalında asılı bir çan bulunuyorsa, altında tanrıyı temsil eden bir obje varsa ki bunlar çoğu zaman üzerine kırmızı boya sürülmüş kaba saba taşlardır, dibine bırakılmış muhtelif sunular da göze çarpıyorsa burası bir yol kenarı tapınağıdır. Çan, Tanrıya geldiğini haber vermek için çalınır. Ziyaretçiler önce bu çanı çalarlar. Çiçek, meyve, tütsü başta olmak üzere özellikle kâfuru veya saflaştırılmış tereyağının yakıldığı basit bir yağ lambası (1ş1k sunusu), bal, pirinç, turmerik (zerdeçal) ve sandal ağacı macunu en yaygın sunulardır. Tanrıça tapınağı için yapılan sunularda kırmızı renk öne çıkar; kırmızı çiçek, kırmızı toz (sindur), kırmızı çaput veya kırmızı ip gibi. Kırmızı, yaşam kanı ile alakalıdır ${ }^{77}$ ve genellikle tanrıçalara yıllık kan kurbanı sunusu yapılır. ${ }^{78}$

Hindistan'ın Tamil Nadu eyaletinde kadınlar Şivaratri gününde amalaki ağacına tapınırlar. Ona çiçek ve meyveler sunar, gövdesinin etrafına kırmızı ve sarı ipler dolarlar. Gucerat eyaletinde de amalaki ağacı en kutsal ağaç olarak bilinir ve bu ağaca tapınılır. Kartik (Ekim-Kasım) ayının dokuzuncu gününde kadınlar, kocalarının soyunun devamı için hayırlı bir erkek evlat dileğiyle bu ağaca tapınırlar. Bu esnada sandal ağacı macunu ve kırmızı boya sunar, ağacın etrafında beş kez dönüp her seferinde gövdesine kutsal ip bağlarlar. ${ }^{79}$ Festival zamanlarında bu çok alışılmış bir davranıştır. Yol kenarı tapınaklarının etrafında insanlar sanki büyük tapınakların kutsal odasını/garbhagrihayı tavaf ediyormuşçasına saat yönünde dönerler. 80

Banyan ağacı da çocuk isteyenler tarafından tapınılan aynı zamanda ölümsüzlüğü temsil eden bir ağaçtır. ${ }^{81}$ Satyavan ve Savitri efsanesine göre Satyavan bir banyan ağacının dalları altında hayatını kaybeder. Bunun üzerine Savitri bu ağaca tapınarak ölüm tanrısı Yama ile cesurca bir tartışmaya girer ve kocasının hayatını geri kazanır, hem de döl elde eder. İşte bu yüzden Temmuz ayının dolunayında evli kadınlar oruç tutarlar ve banyan ağacının çevresini dolanırlar, kocalarına uzun bir ömür için dua ederler. ${ }^{82}$

İyileştirici güçleriyle meşhur olan kimi tanrıların tapınakları şifa umuduyla ziyaret edilir ve adak sunuları bırakılır. Bu iş bazen kayıp bir sığırı bulmak için de yapılır. Yolcular emniyetli ve rahat bir yolculuk yapmak amacıyla yol kenarı tapınaklarında dua ederler. Satiler için yapılan tapınaklarda onların koruyucu güçleri için dua edilir. Aynı şekilde "yedi analar" veya "yedi kızlara" da korunma amaçlı dua edilir. ${ }^{33}$ "Engellerin efendisi" veya "başlangıçlar ve başarılar tanrısı" olarak tanınan Ganeş’in tapınağında yolcular güvenli ve başarılı bir yolculuk için dua ederek onun koruması altında engellerin üstesinden gelebileceklerine inanırlar. ${ }^{84}$ Okul yakınlarındaki tapınaklar başarılı olmak için dua etme ihtiyacı duyan öğrencilerin, hastane yakınlarındaki tapınaklar şifa umudu ile hasta ve hasta yakınlarının uğrak yeridirler. ${ }^{85}$

\section{Sonuç}

Diğer tüm dinlerde olduğu gibi Hinduizm'de de Tanrı ile iletişimin kurulduğuna inanılan kutsal yerler vardır. Yol kenarı tapınakları da bunlardan birisidir. Hindu inancına göre bunlar, Tanrı'nın her yerde bulunmasına rağmen onun insanlar arasında sürekli olarak bulunduğunun göstergesi olarak ortaya çıkmış yapılardır. Büyük tapınakların basit ve erken formu olarak görülen bu mekânlar günümüzde de sayısız çeşitlilikte ve değişik karakterlerde varlıklarını sürdürmekte ve gündelik yaşamdaki dini gereksinimler için halk arasında cazibe merkezi olmaya devam etmektedirler. Onların kolay ulaşılabilirlikleri, büyük tapınaklardaki ritüeller için zorunlu olan kurallardan bağımsız oluşları, her kasttan ve sınıftan insana açık olussları, Tanrı ile iletişimde aracıların ortadan kalkması, buralarda ibadet etmenin basitliği ve kolaylığı gibi nedenler halkın onlara olan rağbetini artırmaktadır. Çünkü Hindu tapımı

\footnotetext{
76 Cush vd., Encyclopedia of Hinduism, 790.

77 Nugteren, Belief, Bounty, and Beauty, 349-351.

78 Cush vd., Encyclopedia of Hinduism, 790.

79 Shakti M. Gupta, Plant Myths and Traditions in India, New Delhi: Munshiram Manoharlal Publishers, 2001, 41; Nanditha Krishna, Sacred Plants of India, New Delhi: Penguin Books, 2010, 158.

80 Diana L Eck, India: A Sacred Geography, New York: Harmony Books, 2012, 21.

${ }^{81}$ Pon Kulendiren, Hinduism a Scientific Religion: \& Some Temples in Sri Lanka, Bloomington: iUniverse, $2012,52$.

82 Bharne ve Krusche, Rediscovering the Hindu Temple, 21.

${ }^{83}$ Cush vd., Encyclopedia of Hinduism, 789.

${ }_{84}$ Hancock, The Politics of Heritage, 87; Subramuniyaswami, Loving Ganesha, 265.

85 Sekine, "Sacralization of the Urban Footpath", 86.
} 
sadece dualar, kutsal metin okumaları ve sunulardan ibaret değildir. Tapınak ibadetindeki amaç darsan yani tanrıyı görme ve onun tarafından görülme arzusudur. Bu "görüş" ise ancak bir tasvir vasıtasıyla sağlanmaktadır. Maksat bu tasviri görmek değil, tasvir vasıtasıyla Tanrıyı görmektir. Yol kenarı tapınakları bu amacı en basit haliyle sağlayan yerlerdir. O yüzden tasvirin şekli de daha ikincil plandadır. Bu yüzden bu tür tapınaklarda çok değişik şekillerde ve sayısız tasvirlerle karşılaşmak şaşırtıcı değildir. İnsanlar buralarda Tanrı ile iletişim kurmak için çok farklı yöntemler uygulayabilirler. Bu yöntemlerin arasında öyleleri vardır ki yüzeysel olarak gözlemlendiğinde Eliade'ın deyimiyle "batıl inanç" olarak dahi nitelendirilebilir. Ama ne olursa olsun Hindular için yol kenarı tapınakları her hâlükârda Tanrının ikametgâhı olarak kabul edilmişlerdir ve günümüzde de insanların minnet, sağlık, bağışlanma, ilahi lütfa erişme, korunma, kurtuluş gibi ve daha pek çok nedenlerle kutsal mekân olarak uğrak yeri olma özelliklerini sürdürmektedirler.

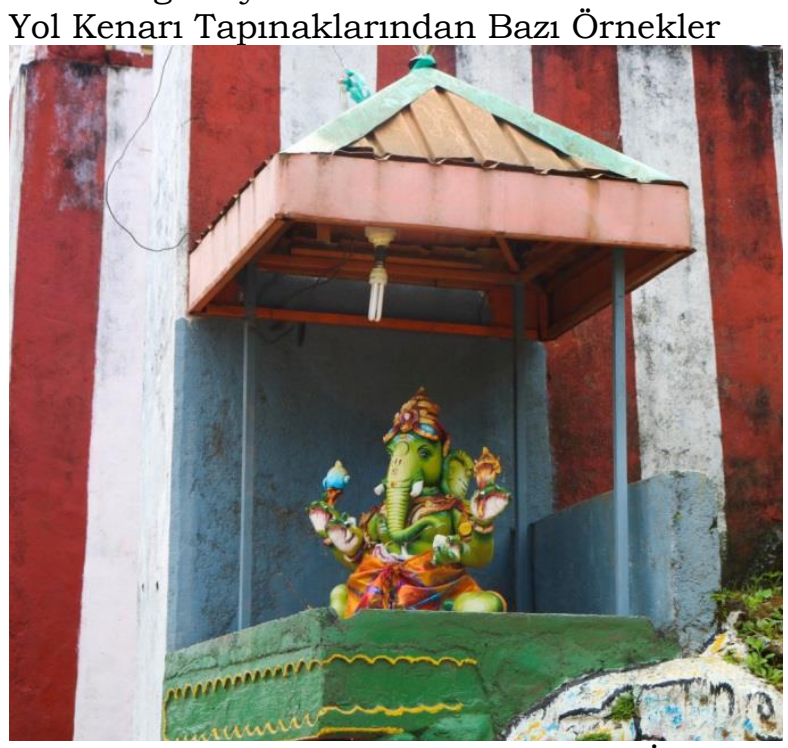

Fil Başlı Tanrı Ganeş İçin Yapılmış Bir Yol Kenarı Tapınağı (Kaynak: http://roadslesstravelledsrilanka.com/news/sri-lankas-hill-country, Erişim: 17.02.2019)

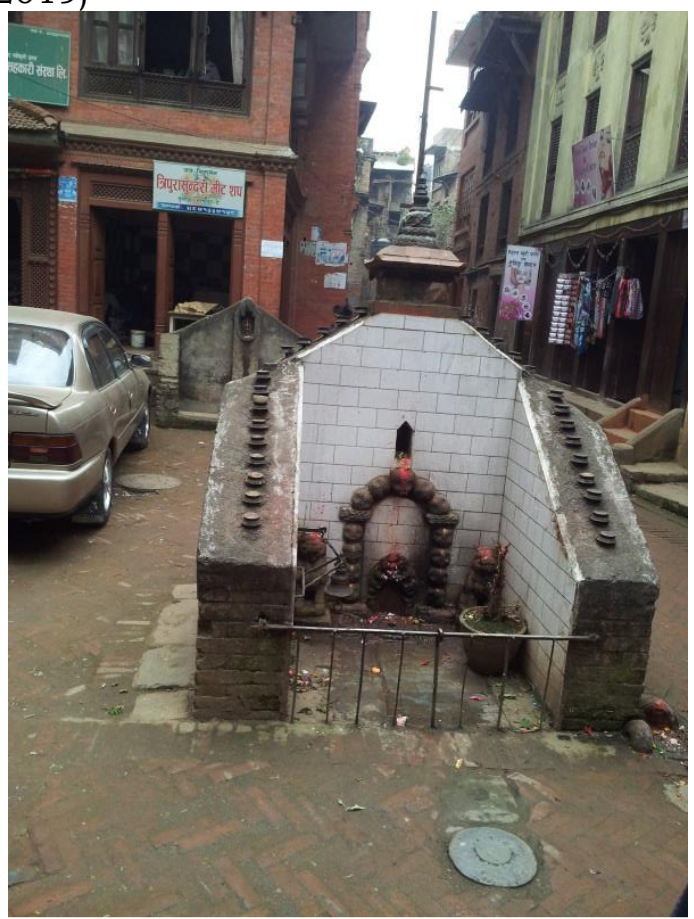

Katmandu'da Bir Yol Kenarı Tapınağı (Kaynak: Yazarın Kendisi) 


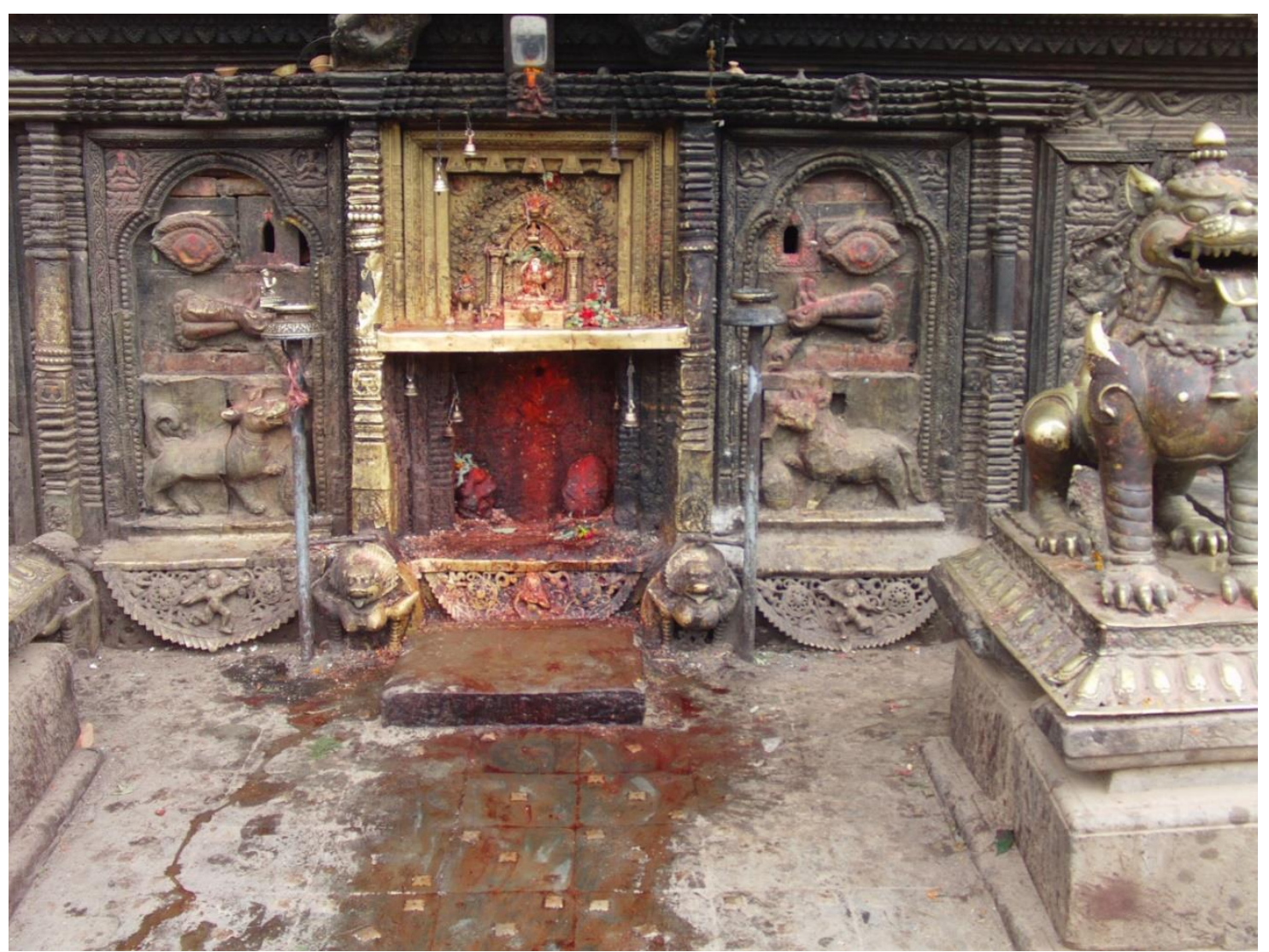

Katmandu'da Bir Yol Kenarı Tapınağı (Kaynak: Yazarın Kendisi)

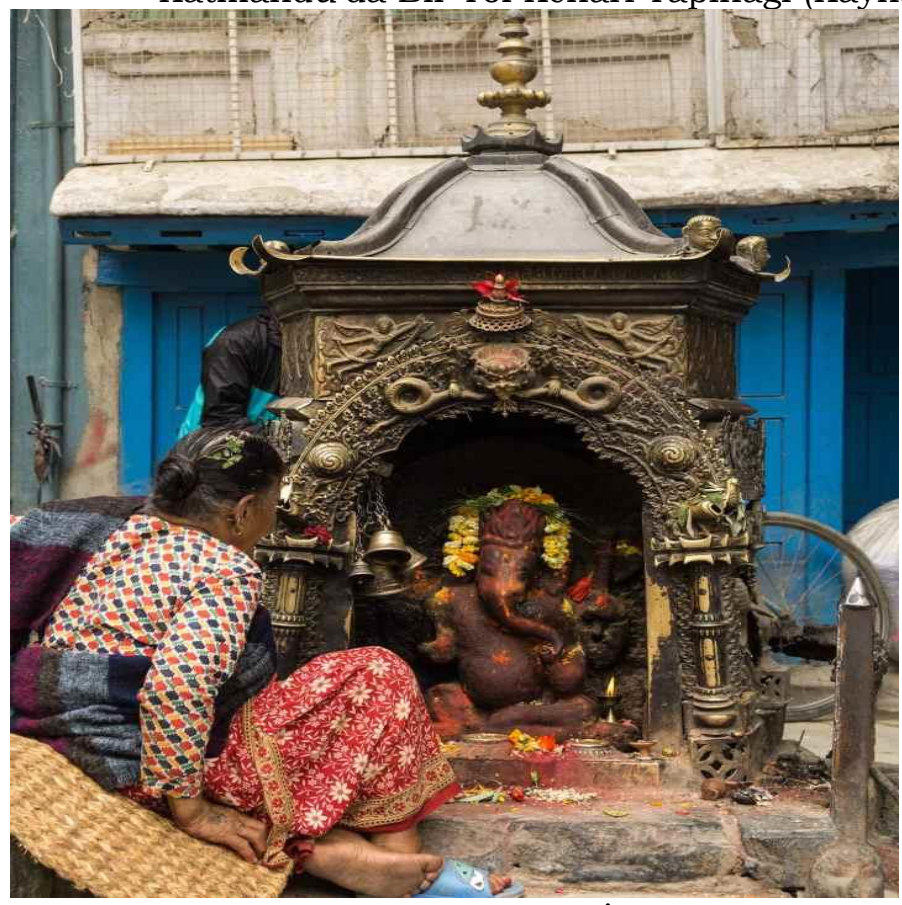

Fil Başlı Tanrı Ganeş İçin Yapılmış Bir Yol Kenarı Tapınağı (Kaynak: https://albinger.me/kathmandu-street-shrine-on-the-way-to-thamel-from-durbar-square/ Erişim: 17.02.2019) 


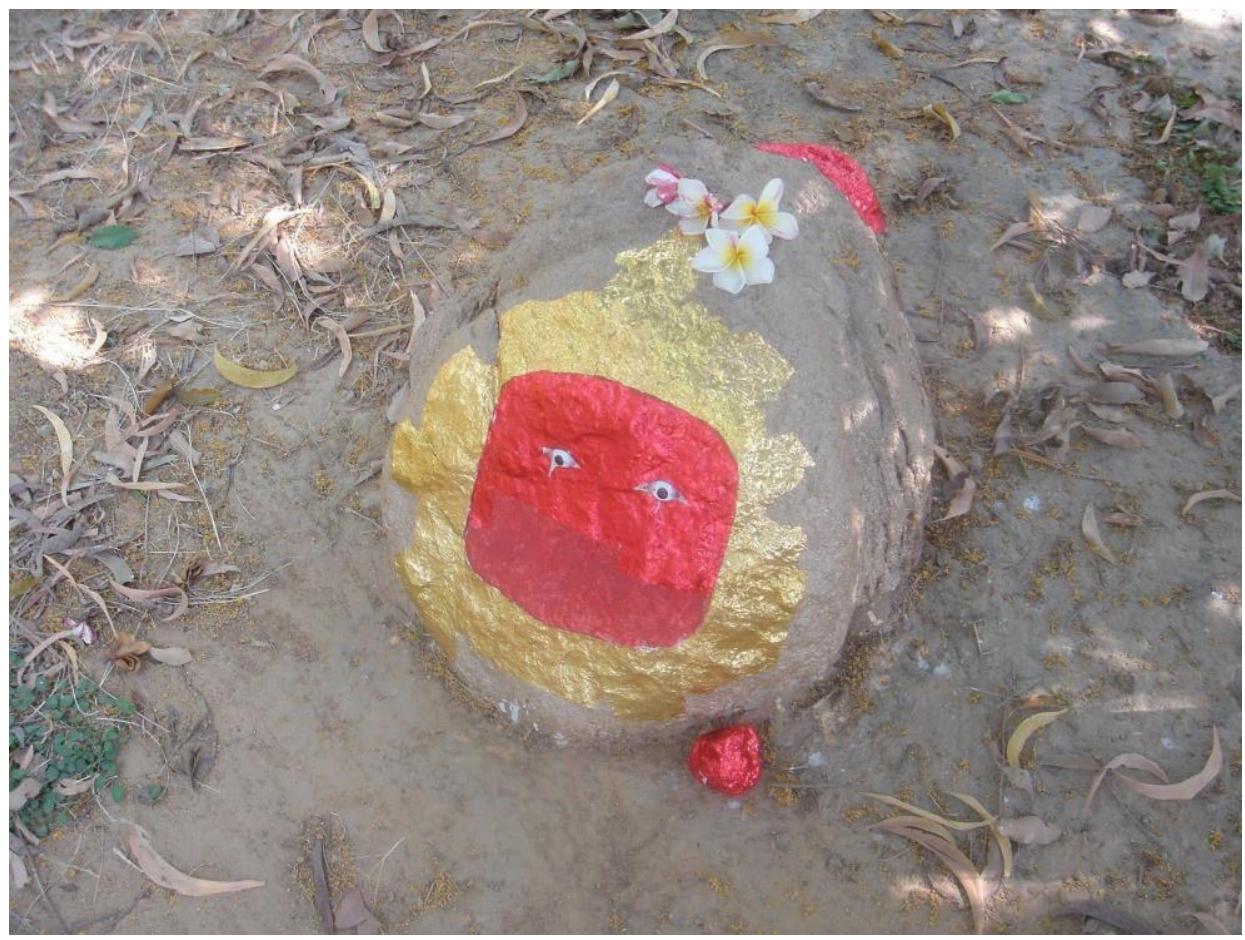

Tanrı'y1 temsil eden tek bir taştan oluşan Yol Kenarı Tapınağı https://tr.pinterest.com/pin/297800594079919656/ Erişim: 17.02.2019)

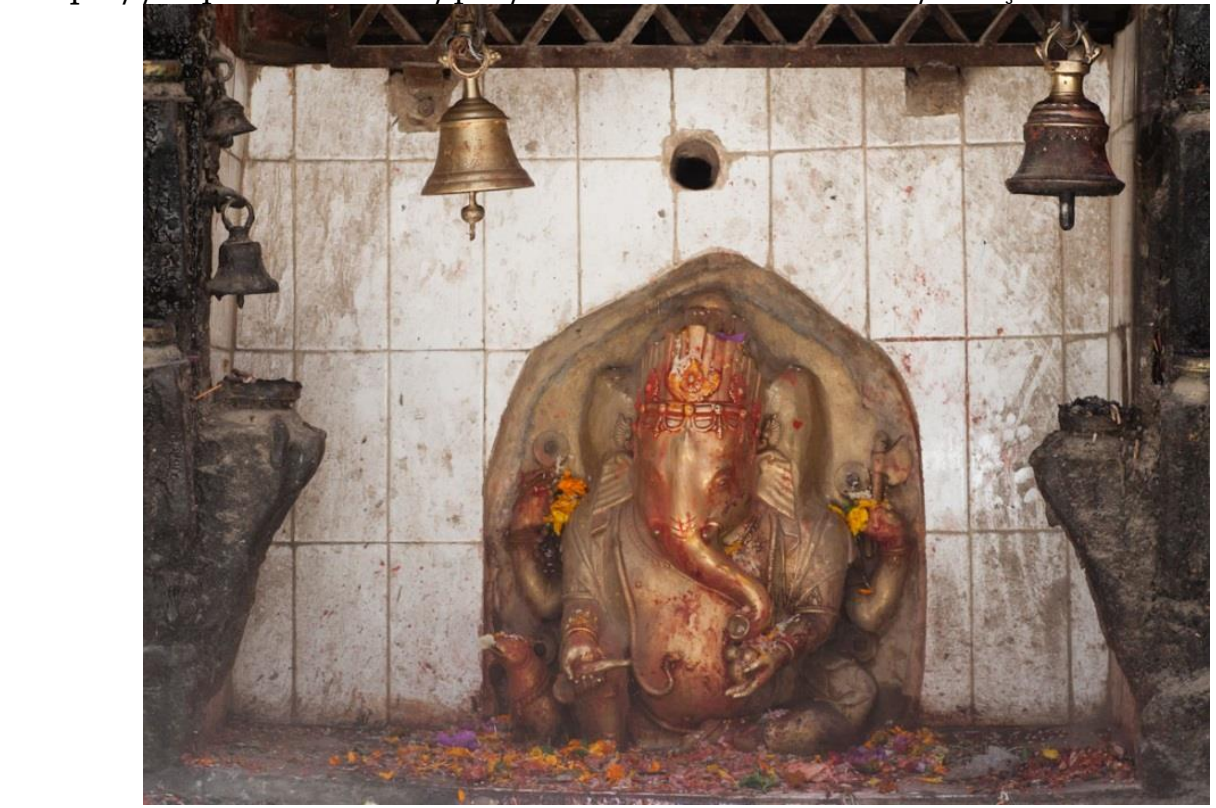

(Kaynak:

Fil Başlı Tanrı Ganeş İçin Yapılmış Bir Yol Kenarı Tapınağı (Kaynak: https://sonyaandtravis.com/kathmandu-nepal-temples-and-cows/ Erişim: 17.02.2019) 


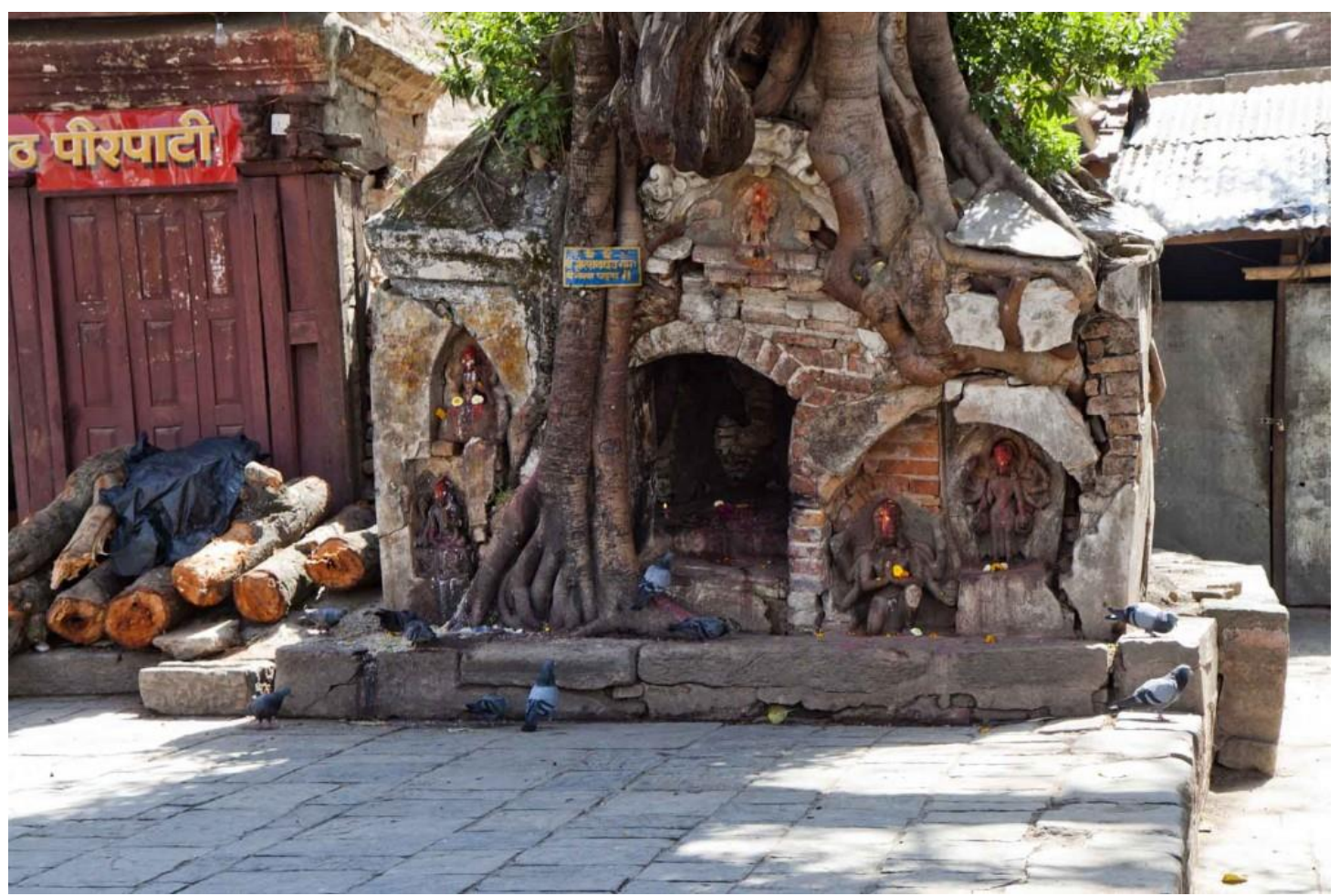

İncir Ağacının Kökünde Maymun Tanrı Hanuman'a ait Bir Yol Kenarı Tapınağ1 (Kaynak:http://www.bontakstravels.com/asia/kathmandu-part-1-thameldurbar-square/\#jp-carousel-10288 Erişim: 17.02.2019)

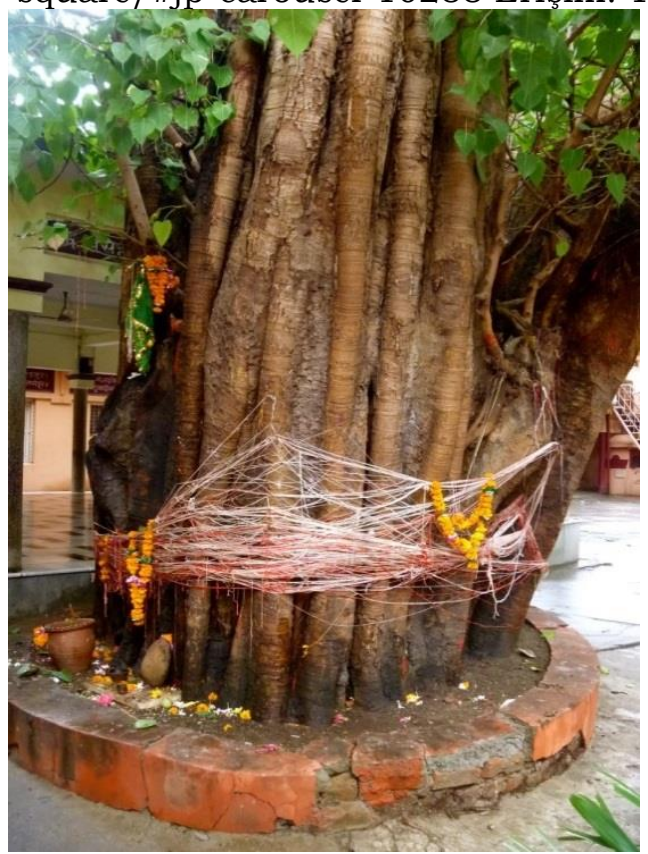

Trimurtiyi temsil eden Hint İnciri Ağacından Bir Yol Kenarı Tapınağı (Kaynak: https://www.flickr.com/photos/amolano/6792793120 Erişim: 17.02.2019) 


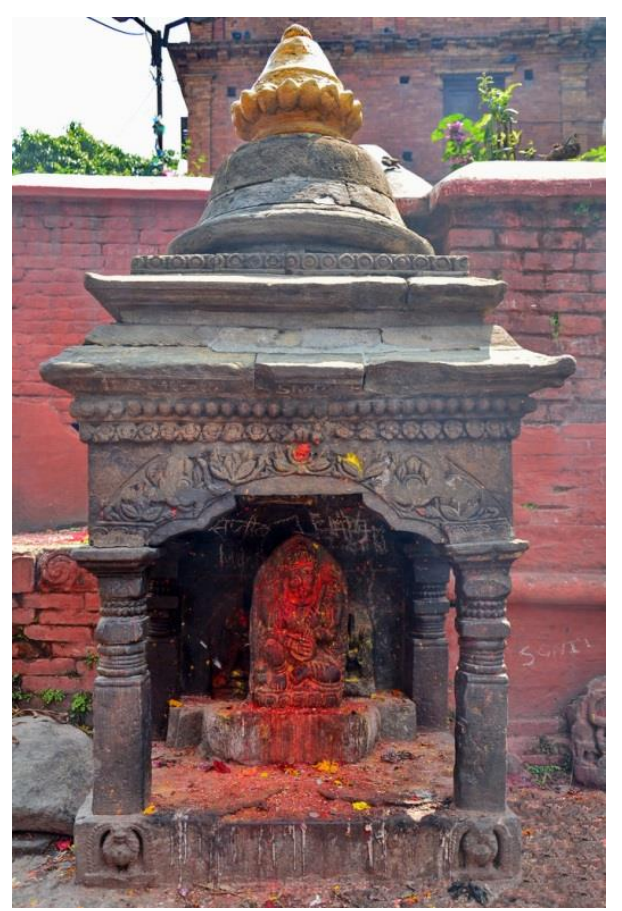

Tanrı Şiva İçin Yapılmış Bir Yol Kenarı Tapınağı (Kaynak: https://www.flickr.com/photos/asienman/21396365474/ Erişim: 17.02.2019)

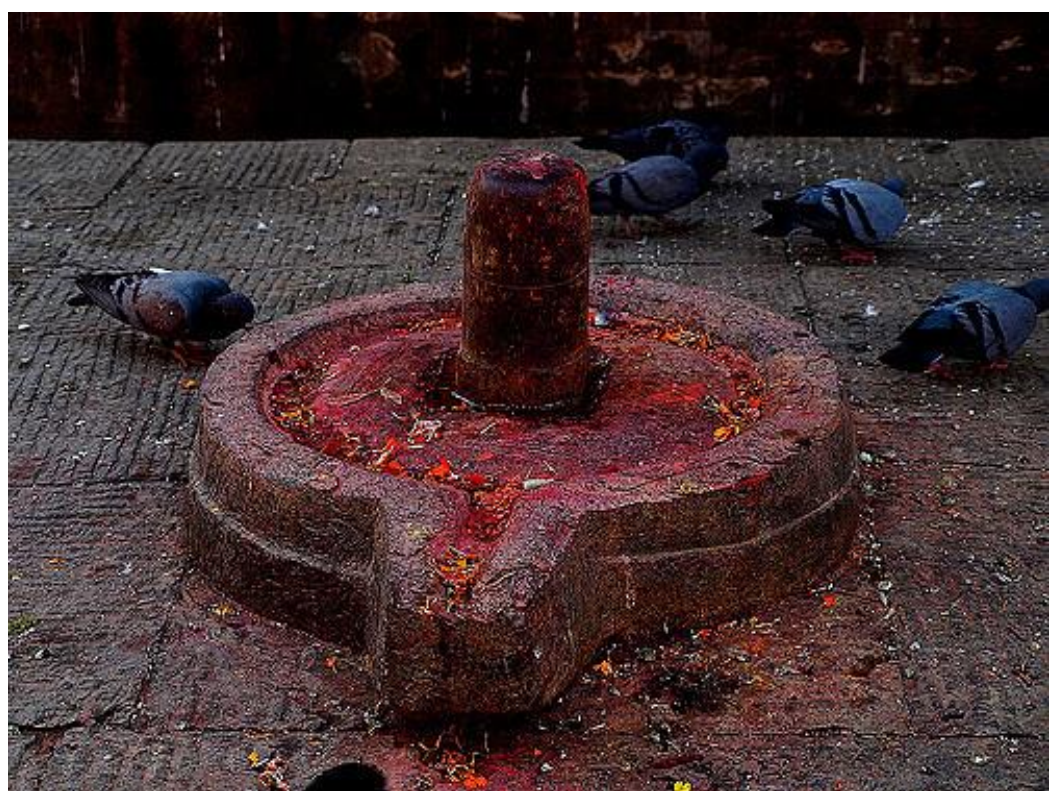

$\begin{array}{cccccc}\text { Linga-Yoni } & \text { Formunda } & \text { Bir } & \text { Yol Kenar1 } & \text { Tapınağ1 } \\ \text { https://www.flickr.com/photos/rgamboias/3097269176/ Erişim: } & 17.02 .2019)\end{array}$

(Kaynak: 


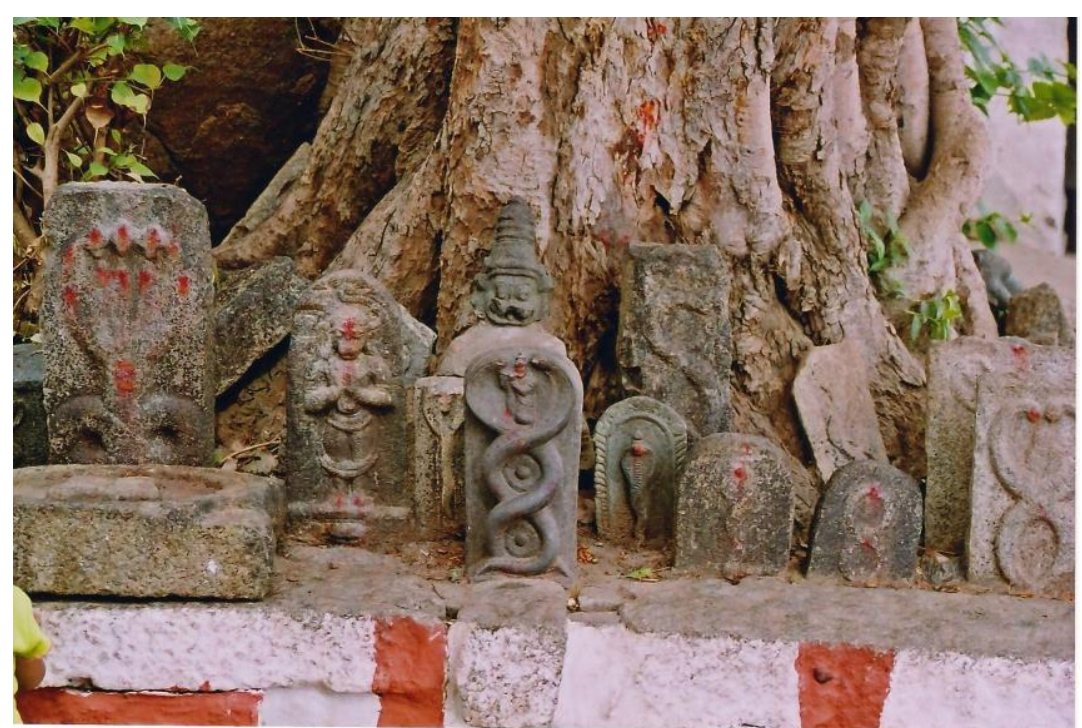

Dibinde Naga (Yılan) Taşları ile Ağaçtan Bir Yol Kenarı Tapınağı (Kaynak: https://tr.pinterest.com/pin/425027283557651813/ Erişim: 17.02.2019)

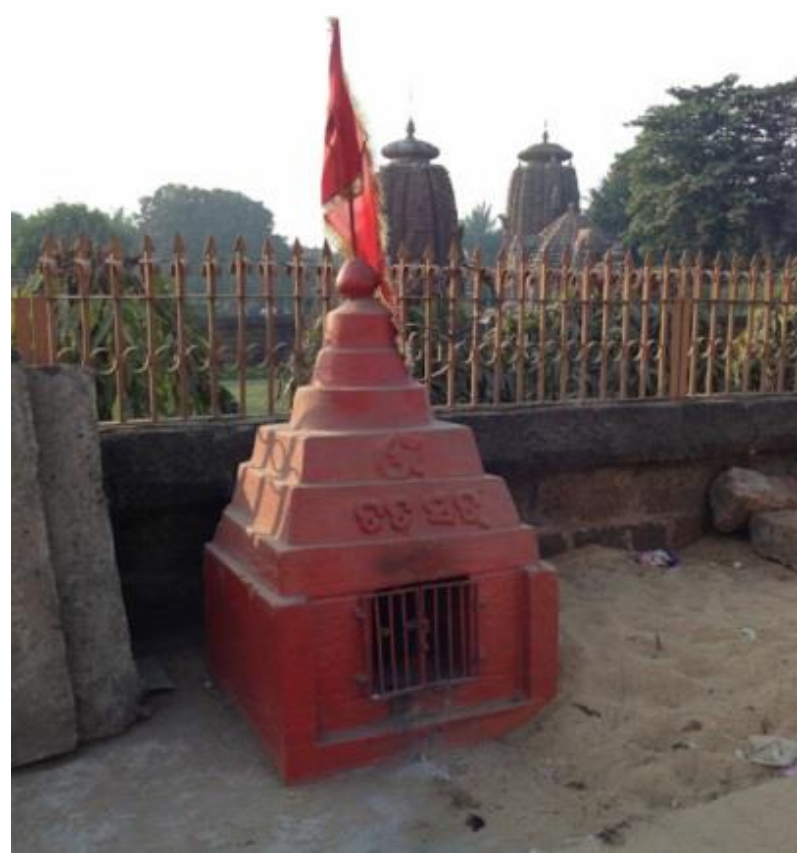

İçindeki Murtiyi Korumak İçin Demir Parmaklık Yapılmış Bir Yol Kenarı Tapınağ1 (Kaynak: https://wovensouls.org/2013/05/26/street-shrines-of-orissa/ Erişim: 17.02.2019 ) 


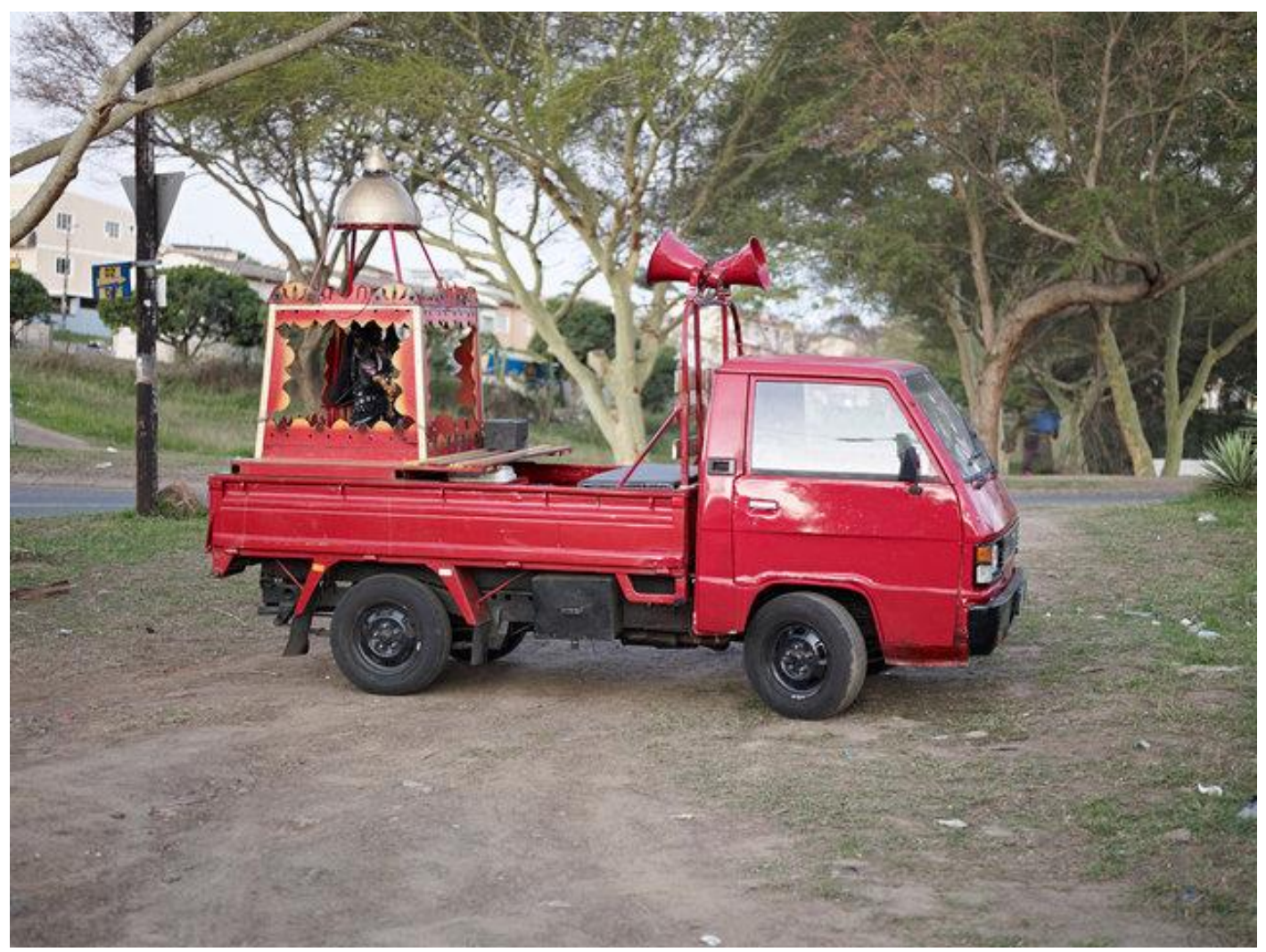

Seyyar Tapinak (Kaynak: https://www.haydenphipps.com/projects-2/indenture, Erişim: 17.02.2019)

\section{Kaynaklar}

Barnabas, Alfred Prabhakar, Social Change In A North Indian Village, New Delhi: Indian Institute of Public Administration, 1969.

Bharne, Vinayak ve Krusche, Krupali, Rediscovering the Hindu Temple, The Sacred Architecture and Urbanism of India Newcastle: Cambridge Scholars Publishing 2012.

Bharne, Vinayak, "Anointed Cities: The Incremental Urbanism of Hindu India", The Emerging Asian City: Concomitant Urbanities and Urbanisms, Edit. Vinayak Bharne, New York: Routledge, 2013, ss.17-26.

Cush, Denise- Robinson, Catherine-York, Michael, Encyclopedia of Hinduism, London \& New York: Routledge, 2008.

Dalal, Roshen, The Religions of India: A Concise Guide to Nine Major Faith, New Delhi: Penguin Books, 2006.

Dalal, Roshen, Hinduism: An Alphabetical Guide, New Delhi: Penguin Books, 2014.

Danielou, Alain, The Hindu Temple: Divinization of Eroticism, Rochester, Vt: Inner Traditions, 2001.

Dorling, Kindersley, Roshen Dalal, India, London: Dorling Kindersley, 2008.

Eck, Diana L., Darsan: Seeing the Divine Image in India, Delhi: Motilal Banarsidass Publishe, 2007.

Eck, Diana L., India: A Sacred Geography, New York: Harmony Books, 2012.

Flood, Gavin D., An Introduction to Hinduism, New York: Cambridge University Press, 1996.

Flueckiger, Joyce, Everyday Hinduism West Sussex: Wiley-Blackwell, 2015.

Ghurye, Govind Sadashiv, Caste and Race in India, London: Kegan Paul, Trench, Trubner 1932.

Grimes, John A., Ganapati: Song of the Self, Albany, NY: SUNY Press, 1995.

Gupta, Shakti M., Plant Myths and Traditions in India, New Delhi: Munshiram Manoharlal Publishers, 2001, 41.

Güç, Ahmet, Dinlerde Mabed ve İbadet, Bursa: Esra Fakülte Kitabevi, 1999.

Hancock, Mary E., The Politics of Heritage from Madras to Chennai, Bloomington, IN: Indiana University Press, 2008. 
Hardy, Adam, Indian Temple Architecture, Form and Transformation : the Karṇāta Drāvida Tradition, 7th to 13th Centuries, New Delhi: IGNCA, 1995.

Harshananda, Swami, All About Hindu Temples, Chennai: Sri Ramakrishna Math, 2001.

Huyler, Stephen P., "Hinduism: The One and the Many", Pratapaditya Pal, Stephen P. Huyler, John E. Cort, Christian Luczanits, Debashish Banerji, Puja and Piety: Hindu, Jain, and Buddhist Art from the Indian Subcontinent, Edit. Pratapaditya Pal, Oakland: University of California Press, 2016.

Jacobs, Stephen, Hinduism Today: An Introduction, London and New York: Continuum, 2010.

Kinsley, David, Hindu Goddesses: Visions of the Divine Feminine in the Hindu Religious Tradition, Berkeley, Los Angeles and London: University of California Press, 1986.

Kramrisch, Stella, The Hindu Temple I, Calcutta: University of Calcutta, 1946.

Krishna, Nanditha, Sacred Plants of India, New Delhi: Penguin Books, 2010.

Kulendiren, Pon, Hinduism a Scientific Religion: \& Some Temples in Sri Lanka, Bloomington: iUniverse, 2012.

Larios, Borayin ve Voix, Raphaël, "Introduction. Wayside Shrines in India: An Everyday Defiant Religiosity, South Asia”, Multidisciplinary Academic Journal, 18 | 2018, URL : http://journals.openedition.org/samaj/4546 ; DOI : 10.4000/samaj.4546. Erişim: 20.10.1018

Lewandowski, Susan, "The Hindu Temple in South India", Buildings and Society: Essays on the Social Development of the Built Environment, Edit. Anthony D. King, London: Routledge, 2003, ss. 67-82.

Michell, George, The Hindu Temple: An Introduction to Its Meaning and Form, Chicago and London: University of Chicago Press, 1988.

Nugteren, Albertina, Belief, Bounty, and Beauty: Rituals around Sacred Trees in India, Leiden: Brill, 2005.

Pancholi, Nila, "Hinduism", Six World Faiths, Edit. W. Owen Cole, London, New York: Continuum, 2002.

Sekine, Yasumasa, "Sacralization of the Urban Footpath, with Special Reference to Pavement Shrines in Chennai City, South India." Temenos, 42(2) 2006, ss.79-92.

Sinha, Vineeta, Religion and Commodification: Merchandizing Diasporic Hinduism, London: Routledge, 2010.

Subramuniyaswami, Satguru Sivaya, Loving Ganesha: Hinduism's Endearing Elephant-Faced God, USA and India: Himalayan Academy, 2000.

Subramuniyaswami, Satguru Sivaya, Dancing with Siva: Hinduism's Contemporary Catechism, Hawaii: Himalayan Academy Publications, 2003.

Voorst, Robert E. Van, RELG: World, Wadsworth: Cengage Learning, 2014.

Wangu, Madhu Bazaz, Hinduism, New York: Chelsea House, 2006.

Whitehead, Henry, The Village Gods of South India, Calcutta: Association Press, 1921. 


\title{
Structures at the Center of the Hindu Community Piety: Wayside Shrines
}

\begin{abstract}
The wayside shrines which are commonly encountered both in urban and rural areas are an indispensible part of worshipping for most of Hindu people. They arise from the Hindu philosophy which assumes that the god is readily available everywhere. Although some of these shrines are dedicated to the great, well-known gods, most of them are dedicated to the local gods and blessed individuals. Among the great gods, Shiva comes in the first place in both picture and statue forms, as well as the other forms. One of the two sons of Shiva, the elephant headed god Ganesh and monkey god Hanuman are commonly seen in these shrines. The local gods that own most of the wayside shrines vary in different regions. In addition, there are also shrines which are built in the memory of folk heroes, mythological individuals or wives who were incinerated alive along with their husbands during their funeral ceremony. These shrines range diversely in terms of structural form. Most of them are simple and flimsy structures in the form of small huts with barely enough space for one to enter and built under a tree. The portraits of gods called "murti" are placed inside these. The essential of temple worship called "darsan", which is "the act of seeing God" is carried out by means of these murtis. The wayside shrines, in the form of a small chamber with their murti inside, are actually the equivalent of the special part of the great temples called "garbhagriha" which means womb room or womb space. Hence, the wayside shrines may be considered as the most basic form of the garish and elaborate great temples. Sometimes, the tree itself is carved into a shrine. Among these trees, the national tree of India, the banyan tree, sometimes called the prickly pear is often encountered. It is even possible to notice the traveling ones among the richly varied wayside shrines. Other times, the wayside gods are out in the open. The practice of worshipping here consists of simple acts. Praying, incense, light, food and flower offerings are the most common practices. Wrapping ropes around the bodies of the sacred trees is another important ritual. Most of these practices may be considered superstitious from a superficial point of view. People go to these places for daily prayers, as well as for different purposes such as health, protection, forgiveness and salvation. As the strict religious rules that have to be obeyed in bigger temples do not apply here, the wayside shrines are open to everyone from different casts and classes. People who serve in these places are usually women and non-Brahmin ones, and even the members of lower casts. Sometimes, there is a self-tasked person devoted to the service of the shrines. Their accessibility and availability for everyone have made them a center of community piety.

Keywords: Hinduism, Worship, Wayside Shrine, Temple,
\end{abstract}

